\title{
Perspectivas na Elaboração Orçamentária (*)
}

\author{
Pedro Koscky Rosa
}

\section{$\mathrm{P}$}

ARA um estudante de Ciências Sociais, no nosso entender, a principal dificuldade que se apresenta na compreensão exata de algum componente social, consiste, precisamente, em vislumbrar os meios, as formas, e os limites, com que cada componente particular concreto dado participa existencialmente de uma realidade social global maior. No que concerne ao assunto dêste trabalho, êsse componente dado seria o "Orçamento da União", que por inumeráveis caminhos vincula-se existencialmente ao "processus" da sociedade global brasileira, da qual faz parte integrante e inseparável.

Essa sociedade global brasileira não constitui um elemento isolado no cosmos, antes, por seu turno, está conjulgada dinâmica e estruturalmente à uma constelação de outras "sociedade globais", com as quais mantém as mais diversificadas relações, que se estendem ao longo de nossas origens històricas até os dias atuais. As nossas instituições sociais, portanto, não admitem que sejam rotuladas, tôdas, como "made in Brazil", já que, pelo contrário, a maior parte delas teve suas sementes lançadas principalmente no Velho Mundo, onde vicejaram. A instituição do orçamento, por exemplo, atingindo sua cristalização efetiva no Brasil depois de longa germinação nas nações européias, que nos forneceram os seus elementos básicos, sejam êstes juridicos, financeiros, contábeis, ou de outra categoria.

Dessa forma, justifica-se, neste trabalho, formular considerações de caráter histórico, jurídico, econômico-social, político, financeiro, sôbre o orçamento, as quais terão o objetivo, não sei se alcançado, de mostrar as ligações existentes entre êsse elemento concreto e a realidade social global em que se insere. Igualmente, tais considerações, poderão informar da transcendental importância que os aspectos jurídicos, financeiros, politicos, econômico-sociais, sobretudo êsses últimos, apresentam para a "elaboração orçamentária" pròpriamente dita. Êsses aspectos correspondem a um verdadeiro "subconsciente" da elaboração orçamentária, que, quando sincera, deverá reputá-los como funda-

( $\left.{ }^{\star}\right)$ Tese apresentada ao Concurso de Técnico de Administração do S.P.F. 
mentais à sua consecução empirica. Aliás, a elaboração orçamentária deve ter sempre em vista que um dia o orçamento entrará em fase de execução, e que essa execução far -se-á dentro de uma realidade histórica, em que uma sociedade certa e determinada, possuindo um contingente humano próprio, que existe de fato, "aqui e agora", isto é, tem um conteúdo inegável de atualidade, e, enfim, que o orçamento irá afetar essa sociedade não só na sua estrutura e dinâmica gerais, como também nas relações entre as classes sociais, e até mesmo suscitando efeitos na vida de cada individuo em particular.

O plano dêste trabalho distribui-se em três partes gerais, na primeira das quais (Títulos I a V) apresento referências sôbre as ligações do orçamento com o contexto econômico-social, em que se insere, e sua importância para a elaboração orçamentária: são aspectos que devem sempre ser considerados por ocasião da elaboração orçamentária, já que o orçamento será executado dentro daquele contexto. Na segunda parte (Titulos $\mathrm{V}$ a IX), procuraremos estudar algumas peculiaridades do processo de elaboração orçamentária, pròpriamente dito. Na terceira parte (Tí.tuilo X), conforme as instruções do Concurso, faremos referências às conclusões práticas dêste trabalho, julgadas convenientes para o serviço público brasileiro.

\section{ESBÔÇO HISTÓRICO E EVDI.UÇÃO DO CONCEITO DE ORÇAMENTO}

Pode-se estabelecer uma analogia aceitável entre o advento do processo orçamentário como tal, com a própria noção da origem do Estado. Nas comunidades primitivas, onde as relações sociais restringiam-se à manutenção de formas precisas que tinham por escopo a sobrevivência do grupo, a divisão do trabalho social e a especialização impostas por êsse objetivo primodial, conduziram a uma estratificação social do poder, permeabilizando-se destarte à eclosão de interêsses diversificados dentro da mesma comunidade, cujas interações e conflitos inevitáveis resultaram na concessão, socialmente aceita ou imposta, de uma supremacia real de um grupo sôbre os outros. FreuD, em "Totem e Tabu", reclama para o "patriarca" a origem primeira dessa supremacia. De qualquer forma, essa supremacia baseou-se na fôrça, e no acatamento social da vontade dessa forç̧a. O poder de vontade de um grupo dominante expresso num acatamento social mais ou menos difuso ensejaria a organização sistemática dêsse mesmo grupo, visando à continuidade histórica de seu dominio: surge o Estado. A sustentação material das necessidades dêsse grupo dominante, e bem assim da comunidade como um todo, só seria possivel se fôsse estabelecido um processo através do qual os bens econômicos e serviços produzidos fôssem canalizados a um esquema distributivo, 
que, de acôrdo com a hierarquia social de poder, outorgasse a cada qual o seu. Naturalmente, que essa situação facilitava a que o grupo social dominante passasse a usufruir um máximo de satisfações, e o restante da comunidade fôsse mantido num mero nível de subsistência. Sem embargo das variações infinitas de organização social em cada sociedade primitiva até os nossos dias, o poder social efetivo liga-se ao conceito de Estado, e a possibilidade de impor sua vontade pela fôrça liga-se à noção de lei, O impôsto é uma lei econômica, já que exige coercitivamente o pagamento de bens ou serviços, em moeda ou em espécie, a uma entidade estatal, ou equivalente, na forma e na quantidade que essa julga adequada.

Se bem que tipos de tributação os mais diversos existissem desde a Antiguidade, a contabilização dos incursos econômicos para o Estado dessa forma de aquinhoar riquezas, sòmente nos tempos modernos adquiriu configuração sistemática.

Da Antiquidade até a Idade Média, malgrado alguns sistemas mais refinados de tributação, a maior percentagem da renda do Estado derivava da simples apropriação de bens e serviços pertencentes a particulares, ao inteiro arbitrio da autoridade pública. Quando êsse ingresso de riquezas não conseguia atender às necessidades da fazenda do soberano, então dava-se ensejo à criação de guerras, com as quais, de forma predatória, espoliavase de outras comunidades parte de sua produção econômica. $\mathrm{Na}$ Idade Média, com a atrofia do poder público e a hipertrofia do poder privado, surge também uma confusão em tôrno do sujeito de direito público e sujeito de direito privado. "A principal característica da Idade Média, do ponto-de-vista político, é a confusão do direito privado e do direito público, do que resultava que o proprietário ou o possuidor de um trecho de terra acreditavarse investido de direitos soberanos sôbre os habitantes dessa região. Outra característica é a formação de uma entidade intermediária, feudo ou comuna, entre o soberano (Imperador ou Rei) e o individuo. Um outro conceito nitidamente medieval consistiu na assimilação do Estado pelo patrimônio privado de uma família, com tôdas as conseqüências que derivam dêste princípio". (1) Essa confusão decorre do fato de que a situação existente entre senhor feudal e servo, outorgava ao primeiro não sòmente o dominio das relações de produção, mas também das condições jurídico-sociais entre ambos. O Direito Romano, em face da inexistência da armadura estatal pura para the dar forma, fenece. Surgem novas formas jurídicas que permitem "legalizar" a situação de servidão: são os contratos de aforamento, "enfiteuse", de direito consuetudinário, que vem configurar uma situação real-

(1) G. Mosca - História das Doutrinas Politicas, pág. 74, ed. 1958. 
mente sem condições de mudanças por parte do segundo contratante, o servo.

A situação perdurará até que pelos inevitáveis conflitos que surgem entre um senhor feudal e outro, a atomização do poder social se encaminha para uma concentração dêsse mesmo poder, nas mãos do senhor feudal mais forte, ou mais sagaz. A pessoa do Rei aparece nessa ocasião, não só aglutinando povos com algumas similaridades sociológicas, forma embrionária das modernas nações européias, como também restaurando o vigor das normas do Direito Romano, que vêm dar ao soberano o arcabouço jurídico de que necessita para impor a sua vontade. $\mathrm{Na}$ turalmente que a pressão populacional, as novas relações de comércio surgidas na Europa, a urbanização enfim, enfraquecendo - feudalismo, constituíram os motivos básicos que facilitam êsse reaparecimento do Estado em sua forma mais pura, o qual passará a funcionar como elemento ordenador da realidade social. Com essa nova situação, as relações entre o Estado e os agentes da produção econômica transformam -se radicalmente, em virtude do caráter monetarizado das transações econômicas, e também da impessoalidade das relações de troca. No sistema feudal puro o servo pràticamente incorporava-se, como coisa, à propriedade territorial. O Estado, na pessoa do Rei, entretanto, ao mesmo tempo que possuía propriedades produtivas, ainda absorvia parte da renda social através da tributação, da cobrança de serviços, etc. Surge uma tendência inevitável de expansão do poder do soberamo. A precariedade intelectual do povo, aliada a uma ambição sem limites dos detentores do poder social, consubstanciariam as condições básicas para o estabelecimento do absolutismo. O Rei passa a tributar da maneira que quer, e sempre o faz de maneira escorchante. Os senhores feudais, os barões, na medida em que suas rendas extraidas do trabalho ainda servil eram em grande parte inelásticas, em face da diminuta capacidade produtiva do sistema e também à pequenez do mercado, não poderiam suportar solicitações tributárias sempre ascendentes por parte do soberano, e, na Inglaterra, reagiram de forma bem conhecida: "impuseram ao Rei da "Magna Charta" de 1.215 , onde, entre outras medidas decerto incluídas para conseguir apoio, fizeram inscrever a famosa disposição: No scutage or aid shall be imposed in the kingdom, unless the common council of the realm..." (2)

A informação de G. Mosca, antes citada, de que na Idade Média, entre o poder do Estado corporificou-se uma entidade intermediária, feudo ou comuna, fornece-nos subsídios para identificar os agentes históricos que se engolfariam em conflitos os

(2) Newton Corrêa Ramalho, Instituições Orçamentárias Fundamentais, pág. 8,1955 , Rio de Janeiro. 
mais violentos visando amealhar o poder social, conflitos êsses oriundos dos antagonismos de interêsses os mais inconciliáveis. Tais agentes: o Estado, ou seu representante hábil (Imperador ou Rei), o baronato feudal em decadência, e a burguesia das comunas em ascendência. A associação transitória dos interêsses da burguesia com o baronato feudal, inclusive pode-se afirmar mesmo que houve uma fusão real dessas duas classes, ensejaria uma frente única de defesa ante a voracidade fiscal do soberano. Essa frente única consubstanciaria a formação dos Parlamentos e Assembléias nacionais, que lutando pela abolição do absolutismo dos Reis, ensejaria um ambiente mais propício à eclosão do desenvolvimento industrial, que, sobretudo a partir de 1750 , iria alterar o "facies" econômico-social do globo. Na Inglaterra, em 1688, Guilherme de Orange, aceitando o "Bill of Rights", aceitava também que todo subsídio seria votado anualmente pelo Parlamento. A obrigação da prestação de contas anuais dos negócios públicos, implicava na necessidade de submetê-las a uma disposição sistemática onde se demonstrariam a origem e o fin dos dinheiros entregues à Fazenda do Rei. Êsse princípio democrático de que os podêres públicos devem fazer uma demonstração de contas anualmente, e também de que a incidência de novos impostos sòmente é possivel mediante a anuência de uma assembléia de representantes populares, passou a constituir motivação básica de quase tôdas as sociedades modernas, que, no en tretanto, sòmente consolidaram tal princípio em seus territórios após penosa evolução e mesmo movimentos revolucionários, como a França (1789), e Estados Unidos (1774). No Brasil, a partir da Constituição outorgada de 1824 , tais disposições democráticas passaram a integrar nossas instituições financeiras públicas. Por conseguinte, a origem histórica do Orçamento prende-se à necessidade de um contrôle parlamentar sôbre o "como" o execưtivo efetuará as despesas públicas, e de que forma encontrará recursos para atendê-las.

Todavia, o próprio poder executivo, tendo que agrupar anualmente o conjunto de despesas e receitas para o exercicio posterior, viu nessa obrigação legal uma excelente ocasião para "pôr ordem na casa", isto é, distribuir os recursos financeiros pelos diversos órgãos sob sua administração, de tal forma que não houvesse interrupção de serviços, ou que as obras públicas não sofressem solução de continuidade. Destarte, configura-se o orçamento, com sua nova função; plano de trabalho do Govêrno. Eis por que, atualmente, em virtude de lenta evolução administrativa, a elaboração orçamentária parte de baixo para cima, isto é, das repartições menores até os órgãos superiores de administração. A razão hásica de tudo isso é que as repartições menores, e tão-sòmente 
elas, dispõem de elementos concretos precisos para medir o alcance das necessidades públicas que lhe são afetas, a possibilidade e capacidade de seu pessoal, e as técnicas que intervêm na execução do serviço. O plano de trabalho, assim determinado por cada serviço particular, irá naturalmente sofrer variações, em virtude d apolitica geral do govêrno, cujas diretrizes cabem aos podêres administrativos centrais. Essa situação permite que o orçamento seja para a Administração Pública um instrumento de programação, desde que canaliza para cada setor administrativo uma proporção adequada de recursos, que serão utilizados na consecução dos serviços e obras públicas julgadas necessárias à comunidade nacional. Por outro lado, cabe assinalar que o orçamento cons titui realmente um instrumento de programação para as repartições individualizadas, mas muito mais ainda para a Administração Pública como um todo, já que oferece um panorama muito aproximado do que será efetivamente executado em determinado ano financeiro. Da mesma forma, ao mesmo tempo em que o Orçar mento é um instrumento de programação, é, também, um instrumento de coordenação, considerando que cada unidade superior coordena a programação das repartições subordinadas, cotejando os trabalhos e as obras a serem executadas por cada qual com os objetivos maiores dos órgãos centrais de administração. As informações de cada repartição em particular, permitem disciplinar as despesas, e saber da adequação dos programas, relacionando-os com os das demais repartições. O Orçamento, por outra forma, adquire feições de um instrumento de comunicação interna, quando propicia informações dentro da própria estrutura administrativa, e comunicação externa quando faz uma ligação entre o executivo e o legislativo, e também entre o Gevêrno e o Povo. Quando da elaboração orçamentária, a Administração Pública disciplina as suas atividades através da programação do trabalho que pretende realizar. Está claro que êste disciplinamento proporciona uma ampla possibilidade de contrôle da administração sôbre si mesma. Aliás, durante a execução orçamentária será evidenciada a adequação e a boa qualidade da programação de trabalho constante da proposta orçamentária, tarefa essa de contrôle que será efetivada pelos niveis superiores da administração. Dessa forma, o conceito fundamental de Orçamento, para as condições modernas de Administração Pública, ultrapassa a afirmação particularizada de LAUPENBURGER: "Le budget ainsi compris apparaît comme un ensemble couvrant le bloc des besoins financiers et des moyens de couverture", (3) pois na verdade não é um mero escalonamento de receitas e despesas, antes encerra

(3) Henry Laufenburger, Traité d'Économie et de Législation Financières - Budget et Trésor — pág. 8, 1948 - Paris. 
todo o valor de um instrumento para a Administração Pública de programação, de coordenação, de comunicação e de contrôle. Mas, está claro que o conteúdo financeiro do Orçamento, realçado por LAUFENBURGER, corresponde a um de seus aspectos mais importantes, se bem que não o único. "Em conclusão, podemos afirmar que o orçamento público se caracteriza, nos dias de hoje, pela programação das atividades governamentais em um determinado período de tempo, geralmente um ano, a previsão dos recursos disponiveis para atender aos gastos correspondentes e à aprovação dêsse programa por um órgão representativo da soberania estatal". (4)

Assim, parece-nos que os traços mais essenciais do histórico e evolução do conceito de Orçamento foram citados, a saber: que - Orçamento liga-se à origem do Estado e das formas de tributação; que a necessidades de um contrôle politico das despesas públicas engendrou a sua contabilização sistemática, anual; que o executivo, paulatinamente, acrisolou a instituição orçamentária tendo em vista mais sua utilidade para a Administração Pública, do que pròpriamente para o contrôle politico.

\section{O SENTIDO JURÍDICO DO ORÇAMENTO}

O Orçamento é um instrumento legal, já que proveniente de entidades públicas juridicamente hábeis, e que produz efeitos jurídicos na criação, ou manutenção, de direitos e obrigações, não só para a própria Administração Pública, como também para os cidadãos particulares. A Administração Pública vê-se legalmente limitada pelo Orçamento a recolher da sociedade sòmente aquelas contribuições tributárias inscritas na lei de meios, bem como suas despesas não poderão ultrapassar as dotações constantes nos quadros orçamentários próprios. A grande reeivindicação democrática de que todo impôsto deve ser votado anualmente, cujo objetivo é claramente o de condicionar ao interêsse geral o poder tributário do Estado, cristalizou-se, nas Constituições modernas, como verdadeiro preceito jurídico, já que tôda contribuição a ser exigida do povo pelo Govêrno, para ter validade, deverá merecer aprovação legislativa e ser consignada no Orçamento. A vasta polêmica que se estabeleceu, sobretudo com juristas alemães, a respeito da significação jurídica do Orçamento, alongou-se durante anos em bacharelices, cediças à verdade, mas de tal forma tumul tuaram o assunto, que grandes rodeios percorreram os estudos de Finanças Públicas, até conseguirem o enfoque adequado da coisa, e o seu claro discernimento. A substância do problema estava

(4) Sebastião de Sant'Anna e Silva - Introdução ao Estudo dos Orçamentos Públicos, pág. 17, 1959 - Belo Horizonte. 
em se considerar ou não o Orçamento como Lei. LABAND defende sèriamente a condição de lei para o Orçamento, mas apenas no sentido "formal", pois o Orçamento, estabelecendo apenas relações "interna corporis", consistia exclusivamente em puro ato administrativo, criando direitos e obrigações apenas para o Govêrno, não constituindo-se lei no sentido "material". JuRANDIR Coelho, sôbre o assunto, expressa-se da seguinte forma: "Assim, ao contrário do que doutrina LABAND, a lei orçamentária contém o seguinte preceito jurídico de ordem geral: o tesouro não poderá efetuar pagamento de nenhuma soma, ainda que a ela o individuo tenha direito em virtude de lei, contrato ou qualquer outro título juridico, se do orçamento não constam os fundos necessários à satisfação da divida, e, reciprocamente, o Estado não poderá exigir do individuo impôsto, contribuição ou outra qualquer prestação tributária, se não figura na lei orçamentária como elemento da receita autorizada. Pelos têrmos dêste preceito, parece que o mandamento é endereçado tão sòmente à Administração e, assim, de acôrdo com LABAND, o orçamento teria apenas um valor relativo, ou limitado tão sòmente aos altos poderes do Estado, interessando, de modo exclusivo, às relações "interna corporis" do govêrno (Poder Executivo e Poder Legislativo). Entretanto, e claro, pelo menos quanto à sua segunda parte, que o preceito é endereçado, igualmente a todos os individuos, ou à generalidade dos cidadãos. Se com efeito, a administração não poderá arrecadar impôsto, criado, embora, em lei de caráter permanente, senão quando contemplado na receita, segue-se necessàriamente, que o impôsto só se torna exigível por fôrça da lei orçamentária, e, assim, o preceito contido no orçamento poderá ser invocado pelos individuos para se eximirem de uma obrigação tributária de que ainda não são devedores". (5) Da mesma forma, Armindo MonTEIRO, compreende que a capacidade juridica do Orçamento participa de sua essência como coisa, configurando-se como lei, no mais lidimo sentido dessa palavra: "o Orçamento tem a mesma fôrça obrigatória que as outras leis; só pode ser alterado ou revogado por via legislativa". (6) A nossa Constituição de 1946, no $\S 1^{\circ}$ de seu art. 73 , tem as seguintes palavras: "A lei do orçamento não conterá dispostivo estranho à previsão da receita e à fixação da despesa para os serviços anteriormente criados". O $\S 34$ do artigo 141, da mesma Constituição, assim reza: "Nenhum tributo será exigido ou aumentado sem que lei o estabeleça; nenhutm será cobrado em cada exercicio sem prévia auto-

(5) Jurandir Coerino - Teotia e Processo do Orçamento, pág. 139, 1952 - Rio de Janeiro.

(6) Armindo Monteiro - Do Orşamento Português - Tomo Primeiro, pág. 90, 1921 - Lisboa. 
rização orçamentária, ressalvada, porém, a tarifa aduaneira e o impôsto lançado por motivo de guerra". Essas disposições constitucionais embora conferindo o título de "lei orçamentária" ao Orçamento da União, fazem do mesmo uma lei formal na parte das despesas públicas, no que se refere às despesas fixas, pois essas serão realizadas consoante legislação anteriormente estabelecida; sendo que, entretanto, na parte da receita, e também no que se refere às despesas variáveis do orçamento, a autorização orçamentária é indesviável da habilitação jurídica do Govêrno para cobrar os tributos e realizar os gastos, constituindo-se nesses aspectos uma lei criadora de direitos subjetivos e obrigações reciprocamente para a Administração Pública e para os cidadãos.

\section{O SENTIDO POLÍTICO DO ORÇAMENTO}

O Govêrno central de uma nação, ao estabelecer um caminho que reputa o mais aconselhado para a boa gestão dos negócios públicos, informa sôbre os componentes básicos de sua "politica". Isto é, expressa-se em recomendações mais gerais para os órgãos superiores da Administração Pública, indicando uma direção unívoca, se bem que ampla, que deverá conjugar todos os esforços da estrutura administrativa do Govêrno, visando atingir seu fim político. Quando o fim político do Govêrno está em uníssono com as próprias aspirações do povo, as funções dos órgãos administrativos decorrerão sem dificuldades, antes encontram receptividade e apoio às realizações governamentais. Igualmente, quan do o Govêrno possui sensibilidade suficiente para perceber o sentido do "bem comum" de cada época, naturalmente não encontrará nos cidadãos estôrvo de qualquer natureza à boa gerência dos negócios públicos. Como no Orçamento devem estar representados, em têrmos financeiros, os objetivos políticos do Govêrno, não há de se temer que a inadequação daquele instrumento da Administração Pública possa desservir a consecução dêsses últimos, se é que êles são coerentes com a vontade do povo. Uma politica num país democrático deve visar o Governo do Povo, pelo Povo e para o Povo, na expressão tão repetida de LiNCOLN, mas sempre atualissima. As finanças do Govêrno, acompanhando essa politica geral, tenderão a atingir um bom resultado econômico-social, sem se transformarem em "brujas" que não cremos, mas que existem. "Há mais de cem anos o Barão Louis, que foi, sem contestação, um grande ministro da Fazenda, teve no Parlamento francês um dito que é todo um sistema de filosofia econômica: "faites moi de la bonne politique, je vous ferai des bonnes finances". (7)

(7) Armindo Monteiro, op. cit., pág. 130. 
Quando abordamos é verdade que sucintamente, o problema da evolução do conceito de Orçamento, pudemos verificar oúe o advento do espírito déemc crático do Ocidente esteve associado intimamente a origem das instituições orçamentárias. O contrôle político dos dinheiros públicos, ou seja o contrôle da aplicaçãı bem ciscriminada da parte da renda nacional arrecadada pelo Govêrno, foi uma aspiração coletiva que levou muitos povas a movimentos revolucienários, o que por si só demonstra da transcendental importância que a administração da fazenda pública encerra. "Nem leis nem ordens, nem revoluções servem em nossos dias para traduzir a orientação dos governos e a situaçăo єconômica, politica e social dos povos como o Orçamento". (8) Na verdade, à medida que o povo tornou-se consciente de que o que mais interessa numa sociedade é a forma através da qual é administrada, e que essa administração poderá ser fiscalizada mediante análise das contas públicas, os movimentos sociais democráticos. em sentido restrito, objetivavam um Orçamento claro e compreensivo, pois, por seu intermédio, compreender-se-á "aquilo que o Govêrno exige do Povo, e está disposto a fazer por êle", (9) ou seja: o Orçamento identifica, inevitàvelmente, o bom e o mau Govêrno. O contrôle parlamentar do Orçamento, ou como se faz atualmente, a discussão da proposta orçamentária pelo Poder Legislativo, constitui um dos mais aperfeiçoados sistemas para - povo fazer um balanceamento da política geral do Govêrno. $\mathrm{Na}$ verdade, quando o Govêrno estabelece seu programa político, não faz outra coisa que a de determinar os objetivos que irão informar a gerência da coisa pública, durante um determinado periodo, bem como indicar os recursos financeiros e os meios administrativos através dos quais aquêles objetivos serão atingidos. Numa democracia representativa, a escolha daqueles obetivos compete a um sistema de correlação funcional entre o Executivo e o Legislativo, em que, cada qual, através da livre discussão e da livre exposição de temas, argumentará sôbre as virtudes de suas idéias políticas, cuja corporificação em lei, posteriormente, representará a escolha do melhor caminho, que geralmente corresponde a um amálgama dos propósitos do Executivo e do Legislativo.

De qualquer forma, na distribuição dos encargos administrativos para cada unidade do serviço público, efetuada pelo Orçamento, e bem assim dos recursos com que cada unidade disporá para os conduzir a bom têrmo, encontrar -se-á a linha politica através da qual o Govêrno espera dirigir os tão citados "destinos

(8) Armindo Monteiro, op. cit., pág. 132.

(9) F. D. Roosevelt, in Sebastião Sant'Anna e Silva, op. cit. pág. 32. 
da nação". O Orçamento, assim, consubstancia-se num plano administrativo decorrente de um programa político". (10)

\section{O SENTIDO ECONÔMICO-SOCIAL DO ORÇAMENTO}

Conforme já tivemos oportunidade de salientar, a origem das instituições orçamentárias, decorreu, sobretudo, da necessidade de se exercer um contrôle sôbre as incursões do Govêrno na realidade econômico-social, de tal forma que não fôssem ultrapassados determinados limites, considerados "ótimos" pela filosofia predominante em cada época. Com o aumento da importância da classe burguesa comercial-industrial, surgiu uma tendência na teoria econômica preconizando uma atividade negativista ao papel do Estado na vida econômica. O Estado, destarte, deveria agir efetivamente apenas no que se referisse à segurança nacional, à ordem interna, e à manutenção da "igualdade das partes", ou seja, do funcionamento da justiça. Se o Estado se limitasse a essas funções, ocorreria um desenvolvimento harmônico da economia, de forma espontânea, já que uma "ordem natural" presidiria ao equilibrio na oferta e demanda de bens e serviços, como informa a escola liberal. Ao Estado caberia, por conseguinte, exercer sòmente aquelas atividades concernentes à segurança nacional, e à distribuição da justiça e ao "estabelecimento daquelas instituições e obras públicas que, embora possam ser vantajosas no mais alto grau a uma grande sociedade, são, todavia, de tal natureza, que o seu lucro nunca poderia compensar a despesa correspondente para qualquer individuo ou pequeno grupo de indivíduos". (11) Entretanto, a própria evolução histórica das instituições econômico-sociais impulsionou o Estado a uma presença mais acentuada na sociedade.

Aliás, condições especiais do comércio internacional, por exemplo, na Inglaterra, dariam as razões básicas pelas quais o Estado passasse a intervir na vida econômica, pela necessidade do estabelecimento de tarifas protecionistas para determinados casos. Além disso, a necessidade de um aperfeiçoamento dos meios de comunicação, transportes, fornecimento de matéria-prima para a indústria incipiente, problemas relacionados à mão-de-obra, etc., consolidou situações em que se fazia necessária a intervenção estatal, sobretudo naqueles investimentos não atraentes para a economia privada, em virtude de seu pequeno coeficiente de lucro, ou nenhum. Assim, a própria economia privada, com o seu desenvolvimento, começou a exigir maior eficácia e maior presença da máquina administrativa do Estado. Por outro lado, grandes

(10) José V. O. Martins, in Jurandir Coelho, op. cit., pág. 103.

(11) Adam Smith, in Seenstião de Sant'Anna e Silva, op. cit., pág. 25. 
problemas sociais, ligados à industrialização crescente, e à urbanização, cometiam ao Estado a incumbência inalienável de legislar convenientemente sôbre trabalho, educação, higiene, etc., bem como de realizar obras públicas que facilitassem o desenvolvimento da economia. Assim, justifica-se, em parte, a noção de WAGNER de que a lei da extensão crescente da atividade pública, particularmente da atividade do Estado, advém, para a ciência financeira, da lei da extensão crescente das necessidades financeiras, não só no que diz respeito às necessidades financeiras do Estado, como também das necessidades financeiras das entidades de economia privada. Eis por que deve haver expansão de uma economia de receitas públicas, para fazer face à necessidade de evolução social. O problema do crescente aumento da intervenção do Estado na realidade econômico-social, liga-se, portanto, inevitàvelmente, à própria ampliação da economia privada, que viria a exigir daquele o papel de ordenador das relações de produção, distribuição e consumo de riquezas. A noção de WAGNER, há pouco mencionada, fornece uma base para a compreensão do problema da expansão das atividades econômicas do Estado, e de uma maior intervenção dêste na vida econômica, não se aceitando mais a obsoleta idéia de que o Estado deve manter-se neutro para não prejudicar o bom andamento dos negócios privados, pois, na realidade, tal neutralismo, nos dias atuais, seria sumamente desastroso.

Nessas condições, o Orçamento já se encontra localizado dentro da Administração Pública, como um elemento da mais transcendental importância, pois através dêle medir-se-á o grau de participação do Estado na vida econômica, permitindo, outrossim, à análise econômica o estudo da conveniência das providências governamentais e sua relação com o desenvolvimento equilibrado da economia. Na França, "les 1.300 milliards que prélèvent les budgets et comptes hors budget ne constituent pas une perte pour l'économie, mais une gigantesque redistribution de revenus et de capitaux par l'impôt et par l'emprunt". (12) $\mathrm{O}$ comprometimento que as finanças do Estado têm para com o desenvolvimento econômico e social, inclusive para a ampliação dos negócios privados, deriva em parte de elevada porcentagem que as atividades econômicas do Estado possuem para com a renda nacional. O conceito de renda nacional, para os limites dêste trabalho, pode ser o seguinte: "suponhamos que avaliamos os fluxos que nascem entre a situação $A$ no tempo $t_{0} e$ a situação $B$ no tempo $t_{1}$. Trata-se de procurar qual o valor acrescido entre êsses dois tempos ao estoque inicial. Esse valor acrescido corresponde ao "conjunto dos bens e dos serviços líquidos obti-

(12) Laupenrurger, op. cit., pág. 3. 
dos por uma economia nacional durante um periodo dado" (F. Perroux). Corresponde ao que foi realmente produzido. Mas, trata-se de saber se êsse produto nacional entrou realmente (in-come) no patrimônio das pessoas privadas que compõem a nação. Concebe-se fàcilmente que para continuar amanhã a produção, ou para fazê-la progredir, não será preciso distribuir ass particulares todo o valor acrescido no período. Assim, é provável que a renda nacional seja inferior ao produto nacional". (13) Para os estudos de contabilidade nacional, o conceito de renda nacional representa algo muito elucidativo, pois oferece elementos quantitativos sôbre o volume dos negócios, e sôbre a produção econômica pròpriamente dita. SAMuELSON afirma que "poderemos dizer, em poucas palavras, que a renda nacional e o produto nacional líquido são o total da soma de tôdas as rendas da propriedade e do trabalho ganhas no decurso da criação do produto nacional". (14)

Entretanto, o próprio SAMuelson, em virtude dos problemas de contabilidade nacional introduzidos pela participação do Govêrno, afirma que "o montante da renda nacional é assim menor do que o valor do produto nacional líquido e a diferença é o total arrecadado de impostos indiretos". (15) De qualquer forma, não se poderá falar em neutralidade das finanças públicas na medida em que "nenhuma pessoa hoje viva, viverá bastante para ver o orçamento federal $(\ldots$ dos EE. UU. ...) descer a menos de 30 bilhões de dólares, ou uma despesa conjunta dos governos federal, estadual e municipal de menos de $1 / 5$ da renda nacional". (16) Da mesma forma, "au moment où le budget français tant ordinaire qu'extraordinaire dépasse, avec près de 1.300 milliards au moins, $33 \%$ du revenu national, nous ne pouvons résister à la tentation de nous attacher surtout à ses incidences économiques au lieu d'envisager le budget simplement comme un cadre juridique des dépenses et des recettes". (17) No Brasil, em 1957, sòmente no que corresponde à União, segundo dados de "Conjuntura Econômica", maio, 1961, página 85, e da Equipe da Renda Nacional; do Instituto Brasileiro de Economia, as despesas efetivas do Govêrno Federal atingiram $13,8 \%$ da renda nacional. Essa porcentagem naturalmente seria bem mais elevada se pudéssemos ter em conta elementos correspondentes aos pagà-

(13) Henri Guitton, Economia Politica, Primeiro Volume, pág. 140 1959 - Rio de Janeiro.

(14) Paul A. Samuelson, Introdução à Análise Econômica, I, pág. 258, 1958 - Rio de Janeiro.

(15) Samuelson, op. cit., I, pág. 271.

(16) Laufenburger, op. cit., pàg. 2.

(17) SAMuelson, op. cit., I, pág. 156. 
mentos realizados, naquêle exercício, pelos Estados e Municipios, e bem assim pelas emprêsas públicas, autarquias, e algumas sociedades de economia mista. Essa alta participação do poder público na vida econômica da nação, que tende cada vez mais a aumentar, é conseqüência do desenvolvimento industrial, o qual, aliás, durante a época da Revolução Industrial (1750-1850), constituiu a razão básica do desprestígio da escola liberal, que passou a não ter o menor sentido em face das novas condições econômico sociais. "Essa ampliação das funções do Estado é motivada, principalmente, por uma causa matriz largamente conhecida: o fenômeno da industrialização e da conseqüente urbanização da vida, na maioria dos países". (18) No nosso modo de ver, a análise de um país como o Brasil sob uma perspectiva econômica, deverá, antes de tudo, considerar alguns aspectos mais essenciais do estágio em que se situa sua indústria. Com relação à evolução econômica da Europa, diz CELso FuRTado que "o advento da economia industrial européia é, de todos os pontos-de-vista, um fenômeno cuja comprensão apresenta extraordinária importância. Do ângulo da teoria do desenvolvimento econômico êsse fenômeno se configura como verdadeiramente transcendental, pois se logramos bem compreendê-lo estaremos capacitados para penetrar a fundo na análise do sistema econômico atual, identificar as diferenças fundamentais que apresenta êsse sistema em seus diversos graus de desenvolvimento, e pers crutar as potencialidades que o mesmo apresenta como instrumento propulsor do progresso econômico". (19) As condições atuais de nossa economia, malgrado a escassez de informações precisas sôbre a situação econômico-social em todo o território nacional, parecem nos indicar que vivemos num país, onde, ao lado de regiões com o mais elevado nível de desenvolvimento, deparamos com outras que ainda não ultrapassaram o sistema de trocas "in natura", ou mesmo vivem sob um processo econômico de mera subsistência. Claro está, entretanto, que as regiões desenvolvidas, não só pelo seu coeficiente de população como também pela amplitude de sua produção econômica, configuram a parte socialmente mais substancial da nação. Por outro lado, longe estamos de atingir as condições de um país em estágio de pleno desenvolvimento. Pelo contrário, possuímos grandes áreas "que se encontram subequipadas de capital em relação à sua população e recursos naturais". (20) A posição de um Go-

(18) José V. O. Martins, in Jurandir Coet.fio, op. cit., pág. 105.

(19) Celso Furtado, Desenvolvimento e Stibdesenvolvimento, pág. 137, 1961, Rio de Janeiro.

(20) Ragnar Nurkse, Problemas da Formação de Capital em Paises Subdisenvolvidos, pág. 3, 1957, Rio de Janeiro. 
vêrno num país nessas condições, ao que nos parece, será de compreender, nos seus devidos têrmos, o processo industrialista, que é o instrumento mais capaz de equipar de capital regiões subdesenvolvidas, e que também está bem no cerne das condições econômicas de um país em processo de desenvolvimento econômico, como o Brasil, na atualidade. A indispensável compreensão do Govêrno para os problemas da industrialização, e também da urbanização, que é fenômeno adjacente, deve-se à multiplicidade de funções que o Estado se vê inapelàvelmente solicitado a atender. No Brasil, mesmo para quem observa a sua realidade econômica apenas superficialmente, deparará com manifestas incongruências. Essas incongruências são sobretudo visíveis no setor industrial, que é o setor da economia que, por assim dizer, configura em tôda a sua peculiaridade o processo de desenvolvimento econômico que se verificar em alguma comunidade moderna nacional. Destarte na situação da indústria, podemos acompanhar a própria evolução da estrutura econômica, pois naquela se incrustam, com maior nitidez, os bons e os maus efeitos da orientação geral dessa estrutura, expressa no plano privado pela política creditícia vigente, e no setor público pelo sistema tributário e pela aplicação dos recursos financeiros do Govêrno, manifestada no Orçamento. No Brasil, a situação sofre variantes organizacionais, já que o Govêrno participa, também, do mercado creditício. Sem embargo de que é no setor privado onde, por falta de uma legislação atualizada sôbre o assunto, encontramos as mais formidáveis incongruências na política creditícia, no que se refere ao setor industrial. Parece-nos a mais elementar verdade dizer que um pais que se propõe desenvolver dentro de um quadro democrático-capitalista, o que se deve fazer em primeiro lugar é capitalizar $\sim$ se... No entanto, em nosso país só transparece uma motivação meramente monetarista em nossos procedimentos econômicos, como se "moeda-papel" significasse "recursos", ou aumento da produção econômica pròpriamente dita. Isso só ocorre, infelizmente, em virtude de certa ambiguidade já institucionalizada do Govêrno relativamente à situação econômica, que se revela no constante apêlo às emissões de papel-moeda, ou de Letras do Tesouro. Naturalmente, que essa atitude do Govêrno se completa diante do caráter obsoleto de administração monetária que identifica nossos grandes bancos, protegidos por uma legislação inadequada, que os conduzem à uma politica de entesouramento improdutivo" "Em um mercado concorrencial bem organizado, tende a haver, em dado momento e local, um preço único para o mesmo tipo de mercadoria. Isso acontece por efeito da ação de especuladores profissionais ou arbitrageurs que se mantêm atentos no mercado, a qualquer diferença de preço de 
uma mercadoria. Desde que surja a diferença, compram êles a mercadoria pelo preço mais barato e vendem-na ao preço mais caro, obtendo lucro na diferença e tendem a fazer com que o preço da referida mercadoria se nivele para todo aquêle mercado". (21) Essa condição tão conhecida de um sistema concorrencial relativamente organizado, existente no Brasil, atualmente, tem criado condições no país a uma corrida de especulações estéreis, conduzindo à elevação do indice de monetarização da estrutura econômica brasileira, que já é mais do que excessivo, em relação aos bens e serviços efetivamente à disposição no mercado nacional. O setor privado procede dessa, em certo sentido justificadamente, porque necessita ressalvar a taxa de interêsse do cruzeiro, constantemente abalada pela inflação deflagrada pelo Govêrno, e, inclusive pelo mesmo setor privado, através dos bancos, face ao abuso de letras de crédito, facilitado pela inatualização da legislação a respeito. Está claro que, quando um país vive assolado pela inflação crônica, a primeira preocupação do empresário privado, e sobretudo do industrial, é saber para onde se canalizam, principalmente, os recursos financeiros do Govêrno, e se há uma relativa propensão à poupança no setor privado, que, em caso positivo, significará um estímulo para investir nas mesmas proporções. Quando há essa propensão à poupança, o sistema bancário reagirá colocando empréstimos a rurto e médio prazo ao empresário privado, conforme a medida certa da taxa de depreciação da moeda. Entretanto, quando em um país em processo de desenvolvimento, as emissões fazem-se à medida que o Govêrno necessita de dinheiro, e que essa necessidade de dinheiro é, como aqui no Brasil, estimada para 1963 em 500 bilhões de cruzeiros, ("Conjuntura Econômica", julho, 1962, pág. 59), compreende-se em parte, que os grandes institutos creditícios elevem grandemente a taxa de juros, não só reduzindo o volume dos empréstimos à grande massa de solicitantes, como também, e principalmente reduzindo os prazos, o que cria problemas os mais insuperáveis para o empresário industrial. Para êsse, como para todo o mundo, o dinheiro nunca é suficiente, face à instabilidade monetária. As dificuldades que surgem para a emprêsa em sistema de desenvolvimento, resumem-se no fato de que o seu capital ainda não é inteiramente produtivo, pois se ela se encontra ainda em fase de instalação, ou mesmo na expectativa de formação de mercados para o consumo de seus produtos, o que aliando-se às reduções coercitivas de sua renda através da inflação, e da alta da taxa de juros real, corresponde ao melhor sistema inventado na ciência econômica para o deses-

(21) Samuelson, op. cit., II, pág. 63. 
tímulo para investir. Sem embargo de que seja reconhecido o surgimento de rendas dessa situação geral, resta saber se há um enriquecimento efetivo da nação, por êsse intermédio... Está claro que a resposta é negativa, já que o aumento da renda nacional verificado em cada período dado corresponde quase a um aumento vegetativo do emprêgo dos fatores de produção, e que poderia ser muito maior se houvesse uma melhor organização da produção, ou algum sinal de planejamento econômico na aplicação dos recursos financeiros do Govêrno brasileiro. A carência de um planejamento bem definido para as atividades econômicas do Govêrno, pode ser considerada como uma das causas básicas dos colápsos que a economia brasileira constantemente se vê ameaçada, o que se manifesta, inclusive, na esfera administrativa, pelo recurso inevitável aos chamados "planos de emergência" ou "planos especiais", cuja proliferação na Administração Pública brasileira está a indicar uma incontendivel ineficácia do poder público. Aliás, a incidência dêsses "planos de emergência" ou "especiais" liga-se ao fenômeno das necessidades sempre progressivas, no seio da comunidade brasileira, face à dinâmica que as condições da vida moderna nos imprimem fatalmente. Retornando, porém, ao problema da inflação no Brasil, cuja importância é da mais transcendental para o processo de elaboração orçamentária, podemos já perceber que a inflação em si não conduz ao enriquecimento efetivo da economia. Está claro que, em determinadas circunstâncias, a inflação poderá conduzir a uma elevação da taxa de capitalização da economia: mas, sòmente a inflação controlada, e subordinada a um planejamento econômico prèviamente estabelecido, no qual as emissões surgiriam na quantidade certa, para evitar um colápso na propensão à liquidez do sistema, ou um desequilibrio na procura e oferta globais. Entretanto, como por um desvio da perspectiva econômica, parece que o Govêrno brasileiro viu na inflação o único meio de capitalizar o país, justamente porque no nosso processo industrial houve uma coincidência no aumento do volume de emissões em determinada época, e o próprio surto dêsse processo. "Chamamos a atenção para o fato de que os capitais adicionais, de que dispuseram os industriais para intensificar suas inversões, não foram o fruto de uma simples redistribuição de renda e, portanto, não resultaram do processo inflacionário, isto é, da elevação de preços. Essses capitais foram criados por assim dizer fora da economia, através do aumento geral de produtividade econômica que advinha da baixa relativa dos preços de importação. Atribuiir à inflação um aumento de capitalização da magnitude do que teve lugar no Brasil entre 1948 e 1952 é uma simplificação grosseira do problema que em nada contribui para 
esclarecê-lo". (22) Constitui um dado elementar da observação que o Govêrno deve encontrar os recursos necessários, para atender ao montante das despesas constantes do Orçamento, e na hipótese de que tais recursos financeiros não possam ser requisitados sòmente da tributação normal, de empréstimos públicos, ou de operações de tesouraria, a máquina de imprimir papel-moeda entrará inexcusàvelmente em funcionamento. Entretanto, essa máquina, por si própria, só faz "dinheiro": não há produção econômica em sentido imediato. "O govêrno necessita de recursos para seu projeto e não apenas de dinheiro. De onde virão êsses recursos em um mundo de pleno emprêgo? Evidentemente, apenas das privações dos individuos. Emitindo novas cédulas, o govêrno poderá pagar mais do que os que usam, atualmente, a terra, o trabalho e o capital; êle poderá absorver os recursos produtivos para seu próprio uso; mas ao fazer isso irá aumentar os salários, os aluguéis e os preços". (23) Parece que está identificado o fato de que a massa de consumidores é que se vê obrigada a fornecer os recursos solicitados pelo Govêrno, quando promove a emissão de papel-moeda. A inflação, corres ponde assim à "creación de un impuesto equivalente al monto de lo emitido". (24) A inflação, portanto, não tem o poder esotérico de equipar de capital uma economia, se o tivesse não haveriam nações subdesenvolvidas no mundo. Os institutos de crédito privado, conhecendo essa situação, conduzem a sua política creditícia de tal forma que não percam mais do que o consumidor indefeso, ou mesmo mais do que o industrial ou o comerciante. A taxa de lucros eleva-se em conseqüência, e o crédito é altamente fiscalizado, para evitar a insolvência nos seus negócios bancários. Apesar dessa defesa bancária estar bem organizada no país, essa situação não nos conduz a um ambiente sócio-econômico geral em que possa haver um desenvolvimento equilibrado. A preservação dessas condições poderá levar o país ao caos financeiro, muito mais cedo do que se espera. Manter os cofres dos grandes bancos cada vez mais cheios de uma moeda que se deprecia, cada vez mais intensamente, não é procedimento que se explique por si mesmo. A poupança torna-se muito dificil, pelo menos a líquida, já que todos ficam interessados em se desvencilhar da moeda, cuja depreciação é excessivamente rápida. A política do sistema bancário brasileiro talvez se justificasse quando da existência do padrão ouro, ou mesmo

(22) Celso Furtado, Formação Econômica do Brasil, pág. 248, 1961, Rio de Janeiro.

(23) Samuelson, op. cit., I, pág. 172.

(24) Hugh Dalton, Principios te Finanzas Públicas, pág. 209, 1948, Buenos Ayres. 
numa economia já consolidada, entretanto hoje o país necessita fortalecer sua economia no sentido de capitalizá-la, e, êsse escôpo, hodiernamente, é impossivel sem inversões liquidas em grande escala na indústria e na lavoura, a fim de que ocorra sem estorvos a remuneração dos fatores de produção. Existe, por conseguinte, no Brasil, um sistema perfeito de estímulo a especulação privada, com vistas à defesa da depreciação monetária. A massa de consumidores, os assalariados principalmente, não dispõem de meios para fazer frente à essa depreciação, que conduz à elevação incessante dos preços do mercado. "La inflación, en consecuencia, causa una redistribución de las rentas en favor de los hombres de negocio, quienes se aseguran garancias considerables e inesperadas a expensas de los asalariados, y en mayor grado aún a expensas de los que perciben entradas fijas en dinero. En resumen, la inflación tiende más bien a intensificar la desigualdad de las rentas y a obrar, en conjunto, sobre la comunidad como un impuesto regressivo y no proporcional, suplementado por un subsidio a los hombres de negocios, a los acionistas ordinarios y a los muchos tipos de especuladores". (25)

O combate à inflação, sobretudo nos paises subdesenvolvidos, engendra situações de fato que colocam seus respectivos governos em condições sumamente incômodas, porque têm de atender ao suprimento dos deficits crônicos que se manifestam nos Orçamentos, por isso que não dispõem de outro meio para debelar tais deficits, excluindo a emissão de moeda. Entre. tanto, a inflação continuada conduz o país a um clima de especulação monetária, dentro do qual, todavia, sòmente respiram algumas restritas camadas da sociedade, as quais não sentem depreciação efetiva sôbre o seu poder de compra. A mão-de-obra assalariada não podendo usar da especulação para manter seu nivel de vida, porque lhe faltam os meios e condições indispensáveis para tal, apelam para reinvindicações de caráter grevista, ou outros sistemas coletivos de pressão, visando aumento de salários, eis porque é constante a inquietação social nos países subdesenvolvidos. A indústria e a agricultura, e mesmo o comércio. são. também, em parte, prejudicados pela inflação, pois apesar de poderem penetrar na esfera das especulações monetárias, e de fato assim o fazem, deve oferecer na contra-prestação de seus negócios mercadorias ou serviços, e não apenas moeda, como ocorre com os verdadeiros detentores da especulação, isto é, os bancos, e o próprio govêrno, que financeiramente nada perdem com a coisa. Os industriais e comerciantes não dispõem de mecanismos de adaptação à instabilidade monetária tão rápidos e eficases como os bancos, face à velocidade da moeda. Aqui no

(25) Hugh DALTON, op. cit., pág. 210. 
Brasil, o Govêrno, através da COFAP, COAPS e COMAPS, procura suavizar o problema, principalmente para que a mão-deobra assalariada não se sinta muito muito solicitada no seu poder de compra, estabelecendo tabelas de preços máximos para as mercadorias de mais largo consumo popular, numa intenção de reduzir a margem de lucro dos negocistas e especuladores. Naturalmente, que a inflação, em condições especialíssimas, e devidamente dosada, poderá manter o equilibrio na procura global, evitando o desemprêgo forçado. "Una inflación moderada, ciertamente, puede integrar el plan de acción de un gobierno y debe rán tomarse las medidas apropiadas para producirla. Pero hay que manternela dentro de limites razonables y hajo un control muy firme, y debe obternese un pronto e visible éxito, pues de lo contrario esa politica puede tener por consecuencia la "fuga" de la moneda y otros sintomas de pánico". (26) A aplicação dessas medidas, todavia, só será possivel com um Govêrno central dotado de alto espírito público, bem como de uma equipe de especialistas que possam dar a êsse Govêrno as informações necessárias à boa consecução de seus fins. Em tal sentido, o Orçamento representa um elemento que deve corporificar o mais elevado aprimoramento técnico, na medida em que esclarece como funciona a redistribuição de parte da renda nacional através do programa administrativo do Govêrno. O Orçamento, de tal maneira, informará aos empresários particulares, e inclusive aos grandes capitais estrangeiros o que se pretende fazer no pais no campo econômico, e quais as garantias que aos mesmos se podem dar, no que tange à estabilidade do sistema, e, conseqüentemente, às possibilidades de percepção de uma margem de lucro normal. Um país em fase de desenvolvimento econômico deve procurar atrair capitais, não sòmente em divisas, mas também em bens de produção e mão-de-obra especializada, mas tudo isso só é possivel quando o Govêrno admite uma política econômica que implique em "responsability for maintaining full employment, safequarding the balance of payments and avoiding inflation". (27)

\section{O SENTIDO FINANCEIRO DO ORÇAMENTO}

Já tivemos oportunidade de salientar que o Orçamento é um instrumento da Administração Pública, que pelos mais diversificados processos, liga-se à uma realidade sócio-econômica, e que, através de providências administrativas particulares, bem coorde-

(26) Hugh Dalton, op. cit,, pág. 342.

(27) Britaln An Offictal Handbook, 1961 Edition, London. 
nadas, procura atender um plano politico prèviamente estabelecido em suas diretrizes gerais, cujos efeitos deverão ocorrer naquela realidade sócio-econômica, visando o aperfeiçoamento do sistema de produção existente, sem mencionar o fim último do bem-estar e do aperfeiçoamento do contingente humano.

Existe, entretanto, um componente hásico que torna essas coisas exequíveis e inter-relacionadas: é o dinheiro. E' a moeda, que, como instrumento de troca, como reserva de valores, ou como meio de pagamento, dá um valor concreto para tudo, e libera bens e serviços para o circuito econômico, e, lógico, sua utilização social. O Orçamento, no seu sentido financeiro, encerra para o Govêrno, em particular, e para a Nação, em geral, um elevadíssimo interêsse, já que corresponde à "estrutura de bens, destinada a prover os gastos públicos". (28) Resta, ainda, assinalar que o Orçamento cometendo a cada setor específico da Administração Pública, recursos destinados à execução de tarefas administrativas próprias, estabelece uma correlação indivisível do plano de trabalho da Administração Pública com o plano financeiro, pròpriamente dito. O simples fato de que o Orçamento é uma prospecção pormenorizada do que o Govêrno pretende fazer num futuro próximo, identifica-nos seu caráter de plano e seu sentido financeiro. Aliás, "um orçamento é, essencialmente, um plano de ação expresso em têrmos financeiros". (29) Como o sentido financeiro do Orçamento não constitui fim em si mesmo, constata-se que o Govêrno, por êsse intermédio, procurará atender determinadas necessidades coletivas existentes na sociedade. processando uma ampla redistribuição da renda nacional, seja na tributação adequada e equitativa, seja na criteriosa aplicação dos fundos públicos. Dessa forma, o Govêrno. através do Orçamento, executa uma série de operações, que resultarão em transferências de poder aquisitivo entre as diversas camadas sociais. Consoante o refinamento técnico que o Govêrno utiliza na consecução daquelas operações, poderemos entrever a sua sensibilidade e atualização para com as necessidades coletivas. O encaminhamento dessas transferências de poder aquisitivo é o seguinte: "estas transferências se realizam por médio del pago de impuestos e por otros medios, de determinados individuais a los entes públicos, y, a la inversa, éstos devuelven lo recibido por medio de los gastos públicos, a otros individuos". (30) E.m sintese. o sentido financeiro do Orçamento indica-nos, de uma parte, no aspecto endógeno da coisa, que

(28) José V. O. Martins, in Jurandir Coelho, o*.; cit., pág. 114.

(29) Pedro Muñö Amato. Orşamentos, pág. 7, 1958, Rió de Jaei:o.

(30) Hugh Dalton, op. cit, pág. 12. 
deve haver uma adequação entre os recursos disponiveis do Govêrno e um escalonamento axiológico das necessidades administrativas, ei doutra parte, no aspecto exógeno da coisa, que as transferências de poder aquisitivo devem ligar-se aos principios básicos de finanças públicas, a saber, do sacrifício minimo éxercido pela pressão tributária, e da máxima vantagem social na aplicação dos fundos públicos.

\section{A NECESSIDADE DE UM ÓRGÃO DO EXECUTIVO ESPECIALIZADO} NA ELABORAÇÃO ORÇAMENTÁRIA

O simples fato de que os poderes judiciário e legislativo dispõem, nas repúblicas modernas, de uma tão vasta rede de atribuições especificas, constitui argumento favorável à iniciativa do poder executivo na elaboração da proposta orçamentária. Da mesma forma, a complexidade das responsabilidades e atribuições que são cometidas an executivo, hodiernamente, como outra face da moeda, estão a indicar que sòmente êsse disporá dos elementos necessários, em seus pormenores, que possibilitarão ao Govêrno prever o volume de recursos que se canalizarão para o Tesouro em um próximo exercício, bem como medir o "quantum" das despesas públicas que deverão ocorrer nos diversos setores administrativos. "En plus des arguments politiques qui militent en faveur de l'initiative gouvernamentale en matière budgétaire, des raisons d'ordre technique conduisent à lui reserver la préparation du projet de budget. Tout d'arbord, le Gouvernement connait mieux que quiconque, grâce aux rapports des Administrations, et les hesoins des services et les rendements probables des recettes. Ensuite, c'est le pouvoir exécutif qui est responsable de l'exécution du budget, aussi est-ce lui qui a le plus d'interêt à le préparer soigneusement. Enfin, le projet de budget est un rouage à tel point complexe et délicat que seul un homme ou un groupe restreint d'hommes peut en assumer la responsabilité. L'homogénéité, qui est la caractéristique essentielle du budget, n'est pas compatible avec l'intervention d'une assemblée nombreuse". (31) $\mathrm{Na}$ verdade, se a elaboração orçamentária fôsse outorgada, por exemplo, a um amplo sistema misto executivo-legislativo, o ambiente tumultuado que inevitàvelmente surgiria, iria prejudicar o bom andamento do serviço, haja vista pela circunstância de que o executivo e o legislativo raramente concordam na forma, e também às vezes no volume, com que são dispendidos os fundos do Tesouro. Por outra forma, caso a elaboração do orçamento fôsse entregue a um sistema inter-ministerial puro, os inevitáveis conflitos que viriam à tona, tendo em vista alcançar a preferên-

(31) Laufenburger, o ${ }^{\prime}$. cit., pág. 25. 
cia de um ou outro Ministério para as dotaçes mais significativas, inapelàvelmente conduziriam os trabalhos a um clima de tal maneira litigioso, que, dificilmente, conseguir-se-ia chegar a alguma solução prática. Com relação a êsse último aspecto, entretanto, convém salientar que a elaboração da proposta orçamentária deverá constituir-se num elemento que consiga a coordenação das atividades administrativas do Govêrno, permitindo-se, outrossim, a racionalização dos serviços públicos referentes a cada Ministério, e à cada repartição ministerial. "A elaboração do orçamento deve ser processo continuo, extensivo a todo os níveis e setores da administração. Cada unidade do govêrno deve participar na preparação do programa, contribuindo com suas experiências e esclarecendo sua razão de ser. Não convém desligar o processo orçamentário da gestão administrativa, da qual é parte integrante, para isolá-lo em repartições especializadas de orçamento, ou centralizá-lo excessivamente nos mais altos escalões da hierarquia". (32) Naturalmente, há o risco do "isolamento especializado" de um órgão central do Orçamento. Todavia, na medida em que exista um sistema de coordenação e comunicação entre êsse órgão central, e a administração como um todo, não há que se temer essa possibilidade. Nesse sentido é, que "é indispensável uma repartição central de orçamento para estimular e coordenar a participação dos vários setores e integrar tôdas as partes no programa geral". (33) Se se considera desejável o aprimoramento da máquina administrativa do Govêrno, tendo em vista o incremento do grau de adequação entre as atividades governamentais e a dinâmica da vida moderna, e, portanto, a progressão das necessidades coletivas, há de se conceder como caráter indestacável do processo orçamentário as técnicas atualizadas de Organização e Métodos. Não é por outra razão, no nosso modo de ver, que Pedro M. Amato refere-se à questão do órgão especializado, central, de Orçamento no Capítulo III ("Problemas de Organização e Métodos") de seu livro anteriormente citado. Por outro lado, "o conhecimento e a experiência da técnica de $\mathrm{O} \& \mathrm{E}$ são, como é sabido, fundamentais nas sugestões para o melhoramento e a economia que podem resultar de uma análise organizacional". (34) Aliás, na administração inglesa, junto ao Tesouro Britânico funciona uma divisão de $\mathrm{O} \& \mathrm{M}$, que coordena essas atividades de $\mathrm{O} \& \mathrm{M}$ com o processo orçamentário, visando à racionalização dos serviços públicos, constituindo-se, assim, em exemplo excelente para o Brasil.

(32) PedRo M. Амato, op. cit., pág. 34.

(33) Pedro M. Amato, of * cit., pág. 35.

(34) Tarras Sallfors, O \&̇ M. na Administração Sueca, pág. 25, 1955. Rio de Janeiro. 
Um Governo possuirá um sistema de administração satisfatório, na medida exata do grau de permeabilidade dêsse sistema ao fluxo evolutivo da sociedade. Ao Govêrno caberá atualizar de tal forma a máquina administrativa, que essa seja susceptível de equacionar devidamente as aspirações gerais do povo, em um dado momento, conduzindo, além disso, a que seja realizado um aproveitamento ótimo dos esforços humanos, coletivos e individuais. Entrementes, a exação com que tais objetivos possam ser atingidos, exige inevitàvelmente a colaboração estreita de uma técnica de elaboração orçamentária com um bom sistema de O \& M. No "Bureau of Budget", dos Estados Unidos, o seu órgão de Organização e Métodos, incumbe-se de formular e coordenar "os programas de aperfeiçoamento do processo administrativo e da organização do Poder Executivo. E' o estadomaior de $\mathrm{O} \& \mathrm{E}$ do govêrno americano". (35) Aqui no Brasil, necessita-se dos benefícios do eficaz funcionamento de um órgão de $\mathrm{O} \& \mathrm{M}$, em colaboração com o sistema de elaboração do Orçamento, a fim de que falhas exclusivamente administrativas sejam expurgadas de vez. No Orçamento para 1962, a consignação "Encargos Diversos" quase atinge 65 bilhões de cruzeiros, ou seja aproximadamente $34 \%$ de tôdas as Despesas de Custeio da União. Isso nos leva a crer que na Administração Pública da União há necessidade - inadiável — de uma unidade central de Organização e Métodos. Igualmente, parece-nos de suma gravidade, o volume dos gastos administrativos com o $\mathrm{Mi}$ nistério da Fazenda, para o qual, em 1962, foi aprovada uma dotação global de 106 bilhões de cruzeiros. Esse numerário representa $24 \%$ da Receita e $18 \%$ da Despesa. Já em 1961, êsses dados, retirados do Orçamento respectivo, eram de $22 \%$ e, novamente, $18 \%$. Enquanto isso, nos Estados Unidos, é verdade que em 1959, essas percentagens representavam: $12 \%$ e $14 \%$. Aqui se manifesta, outra vez, a necessidade de um órgão superior de $\mathrm{O}$ \& $\mathrm{M}$, conforme já notamos com relação ao elevado preço dos "Encargos Diversos", nos Orçamentos da União. No nosso ponto-de-vista, tal unidade superior, e central de $O \& \mathcal{E}$, não só deveria estar ligada intimamente à Divisão de Orçamento e Organização do D.A.S.P., com funções reais, e eficazes, naturalmente, mas também vincular-se às unidades descentralizadas de $\mathrm{O}$ \& $\mathrm{M}$ de cada Ministério, as quais, por seu turno, deveriam estabelecer conexação íntima com as Divisões de Orçamento ministeriais, ou Comissões de Orçamento, conforme a nomenclatura prevalecente nos Ministérios Militares e no Ministério da Fazenda. Condições técnicas, portanto, indicam a necessidade de

(35) J. Teixeira M'achiado JR., Administração Orçamentátia Comparada, Brasii -- EE. UUU., pág. 13, 1960, Rio. 
um órgão especializado do executivo na elaboração orçamentária, a fim de que a arrecadação dos recursos e o emprêgo dos fundos públicosc, faça-se consoante um plano de trabalho devidamente coordenado, e integrado nas suas linhas e objetivos mais gerais. Aliás, a criação do "Bureau of Budget", nos Estados Unidos, levou em consideração, sobremaneira, êsse aspecto técnico da questão. "Tudo leva a crer que tanto o próprio orçamento federal como a criação de um órgão especializado para a administração orçamentária nos Estados Unidos, tiveram... a finalidade precipua de concentrar autoridade executiva nas mãos do Presidente, no que se refere à administração do Poder Executivo, além, é evidente, das finalidades de eficiência e economia tão largamente reclamadas pela opinião pública". (36) Em sintese: constitui ponto pacífico que ao Executivo deve pertencer a iniciativa em matéria orçamentária. A complexidade técnica da elaboração orçamentária, requer para sua boa consecução um órgão especializado, central. A necessidade de constante aperfeiçoamento da máquina administrativa do Govêrno, torna indispensável a correlação funcional entre o órgão incumbidos da elaboração orçamentária com uma unidade superior de Organização e Métodos, matriz de uma rede de $\mathrm{O} \& \mathrm{M}$ para tôda a Administração Pública .

\section{OS PRINCÍPIOS ORÇAMENTÁRIOS, E SEU RELACIONAMENTO À TÉCNICA DE ELABORAÇÃO}

Um sistema orçamentário deverá possuir mecanismos de adaptação, de tal forma maleáveis, que consiga manter um índice ótimo de adequação às modificações que normalmente ocorrem na sociedade em que atuar. A chamada "crise" dos princípios orçamentários, decorre, em grande parte, do fato de ter sido hipotecado aos mesmos um conceito de imutabilidade. Essa rigidez conceitual naturalmente não poderia acompanhar o rítmo das novas atividades que foram cometidas ao Estado, face às próprias solicitações do evolver social. Por outro lado, tais princípios surgiram como normas gerais, cujas conclusões sòmente possuiriam significação para condições concretas também gerais, sendo que "em cada aplicação particular devem os mesmos ser tratados como postulados que exigem defesa e justificação". (31)

Neste trabalho iremos abordar, sucessivamente, os seguintes princípios: universalidade, unidade, não-afetação de receitas, autorização prévia, especificação, anualidade, exatidão, clareza, publicidade e exclusividade.

(36) J. Teixhira Machadj JR., op. cit., pág. 10.

(37) J. Wilner Sundelson, in Jurandir Coelho, op. cit., pág. 72. 
O principio da universalidade contém a noção básica de que "tôdas as despesas e receitas do Govêrno devem enquadrar-se no mecanismo orçamentário e submeter -se a processo orçamentário em vigor". (38) A maior defesa que se pode fazer ao princípio da universalidade, reside na elementar constatação de que se no mecanismo orçamentário há alienação de cifras correspondentes a receitas ou a despesas, haverá uma dissimulação da realidade das contas do Govêrno, o que de forma alguma poderá acontecer num regime democrático, pois, nesse caso, a sinceridade e o contrôle da política orçamentária tornar-se-iam inexequiveis. "La sincérité et le contrôle du budget ne sont assurés que si toutes les dépenses et toutes les recettes figurent séparément dans le plan de prévision". (39) Sem embargo de que o principio da universalidade é estudado conjuntamente com o da unidade, não há porque se afirmar que a pluralidade de documentos orçamentários prejudique a universalidade das contas de previsão do Govêrno, sendo mesmo aconselhável que determinadas atividades econômicas sejam dispostas num quadro orçamentário próprio, conforme, no Brasil, deverá ser o caso das autarquias. Pensamos que quando houvesse despesas do Govêrno para com tais entidades descentralizadas, deveriam ser consignadas globalmente no Orçamento da União para cada autarquia, e cuja aplicação devida seria explicitada analiticamente em seu próprios orçamentos, que, no entretanto, deveriam se constituir como "anexos" daquêle Orçamento da União, efetuando, dest'arte, um desmembramento meticuloso das contas dessas instituições. A Lei 830, de 23 de setembro de 1949, artigo 139 , tem os seguintes dizeres: "Consideram-se entidades autárquicas:

a) o serviço estatal descentralizado com personalidade jurídica, custeado mediante orçamento próprio, independente do orçamento geral;

b) as demais pessoas jurídicas especialmente instituídas por lei, para execução de serviços de interêsse público ou social, custeados por tributos de qualquer natureza ou por outros recursos oriundos do Tesouro". As entidades autárquicas, apesar de serem custeadas por orçamentos próprios, e de disporem das chamadas receitas para-fiscais para atender os seus gastos, recebem, continuamente, recursos do Govêrno da União, em virtude da precariedade financeira que caracteriza algumas delas. A realidade dessas operações deveriam estar melhor explicitadas no sistema orçamentário brasileiro, e o melhor procedimento técnico para tal objetivo seria o de que se fizesse demonstrações

(38) Sundelson, in JuRandir Coelho, op. cit., pág. 77.

(39) Laufenburger - op. cit., pág. 45. 
"em anexo" ao Orçamento geral da União. Mesmo no caso de autarquias que fôssem custeadas ùnicamente com seus recursos próprios, seriam da melhor conveniência que seus respectivos orçamentos acompanhassem o da União em anexos próprios, $e_{\text {: }}$ inclusive, que o processo de tramitação no Congresso da proposta orçamentária da União fôsse realizado com o de tôdas as autarquias, observando-se, naturalmente, a autonomia juridica e administrativa dessas instituições descentralizadas do serviço público. Em situação idêntica deveriam se enquadrar as sociedades de economia mista, e também o Departamento Nacional de Estradas de Rodagem (D.N.E.R.), cuja receita é vinculada ao Impôsto Ứnico sôbre comubstiveis, sem mencionar o "fundo sindical", advindo do impôsto sindical, e o "fundo de reaparelhamento econômico" destinado ao Banco Nacional do Desenvolvimento Econômico. Sòmente a articulação unificada de tôdas essas entidades num mesmo mecanismo orçamentário, que teria a preeminência do Orçamento geral da União, poderia preservar o princípio da universalidade orçamentária no Brasil, o que é, incontestàvelmente, um dos esteios de qualquer sociedade democrática que se preze. As facilidades que tal unificação concederia à planificação das atividades governamentais, à sua coordenação, e ao seu contrôle, compensariam de muito o aumento de serviços burocráticos decorrentes. O problema da inclusão de entidades semi-públicas no mecanismo orçamentário, por outro lado, não constitui um procedimento de "centralização" ou "burocratização" de suas atividades, antes pretende unificar globalmente a intervenção estatal no meio social, coordenando-a cientificamente. "No que toca às unidades nacionais, porém, órgãos semipúblicos, instituições autônomas ou organizações privadas subvencionadas freqüentemente exercem funções de govêrno, executando operaçôes financeiras que deveriam ser incluidas no sistema orçamentário". (40) Está claro que tais "desiderata" sòmente seriam conseguidos mediante alteração da legislação em vigor, e mesmo da Constituição Brasileira. Mas o que se pode fazer no Brasil para o aperfeiçoamento de sua máquina administrativa sem alterar o seu universo juridico-legal?

O principio da unidade orçamentária refere-se a que tôdas as receitas e despesas estatais estejam configuradas num único documento. À primeira vista, êsse conceito refere-se ao aspecto formal do Orçamento. No entretanto, o sentido dêsse princípio é de que "todo o material financeiro deve ser apresentado em um único orçamento, de modo que simples somas dêm os totais das despesas e receitas. Um sistema de orçamentos múltiplos

(40) Sundzlson, in Jurhndir Coelho, op. cit., pág. 78. 
incompativel com o conceito de unidade, pode, no entanto, estar em perfeito acôrdo com o principio da universalidade". (41) $\mathrm{Na}$ nossa reinvindicação para que aquelas entidades semi-públicas no Brasil passassem a se submeter integralmente ao sistema orçamentário em vigor para a União, embora o principio da unidade fôsse estremecido formalmente, e na verdade nem é cumprido na atualidade, não o seria de fato, pois as simples somas de receitas e despesas de cada orçamento em particular, forneceria os elementos para se saber com exatidão a efetiva realidade do setor píblico federal da economia. Entretanto, as receitas e despesas de cada autarquia manteriam sua plena independência. A grande problemática dessa questão, naturalmente, seria a unificação das contas dessas entidades semi-públicas no sistema contábil vigente no Orçamento da União, a fim de que fôsse exequiivel a soma aritmética das parcelas gerais de receitas e despesas, o que constitui um aspecto técnico dos mais complexos, ante a variabilidade de receitas e despesas de cada uma daquelas instituições.

O principio da não-afetação de receitas, é, provàvelmente, o mais desrespeitado de todos, já que é pràticamente impossivel estabelecer a "pureza" de caixa no sistema administrativo das nações modernas. Aliás, a nossa Constituição Federal contém diversos dispositivos determinando a aplicação de certas percentagens da receita a algumas atividades governamentais. Em 1960 , essa vinculação de receitas atingia $22 \%$ do Orçamento da União (vd. Relatório das Atividades do D.A.S.P. 1959, Serviço de Documentação, 1960, pág. 16). Por outro lado, a vasta gama de atividades que o Estado moderno é chamado a realizar, torna êsse princípio da não-afetação de receitas de difícil aplicação, pois os governos vinculam percentagens da receita a determinadas espécies de gastos, para o desenvolvimento econômico, por exemplo, com vistas a um mínimo de continuidade na execução dos programas.

O principio da autorização prévia é, ao contrário, aquêle que quase não sofre restrições da parte dos teoristas de Finanças Públicas. Significa que as receitas e despesas do Govêrno devem ser aprovadas por uma assembléia representativa, a fim de que se dê consecução ao exercício financeiro. Êsse princípio, que é uma das grandes conquistas democráticas do mundo ocidental, deverá se estender também a tôdas as atividades financeiras do Estado, inclusive aquelas de administração descentralizada. Tal princípio entretanto, caso não possa ser cumprido, como aconteceu na Alemanha nazista, e na Itália Fascista, não impede que - Orçamento deixe de funcionar, ante as caracteristicas técnicas

(41) Sundelson, in Jurandir Coelho, op. cit., pág. 80 . 
que êsse possui, e que são indispensáveis à manutenção e funcionamento dos serviços públicos.

A especificação é um princípio que advoga que as receitas e despesas do Govêrno não devem ser consignadas no Orçamento de forma global, mas discriminadamente. A especificação será qualitativa, quando a utilização das verbas se faz para as finalidades pré-estabelecidas no Orçamento, e será quantitativa na medida em que os limites das dotações não possam ser alterados. A grande validade dêsse princípio é evitar o tumulto nas finanças governamentais e bem assim o desvio de verbas, ou os chamados "virements". Por outro lado, essa especificação deverá ser realizada no mais alto sentido técnico, a fim de que não suceda a pulverização de dotações, e a desarticulação dos programas de trabalho. A especificação contribui, outrossim, para esclarecer para onde se canalizam os fundos públicos, e sua provável influência em cada setor da economia pública e também da particular.

A anualidade do orçamento público, decorreu de uma necessidade parlamentar de verificar periòdicamente a situação das contas do Govêrno. Atualmente, a sua grande utilidade consiste na obrigação da administração estatal de fazer um balanceamento geral de suas atividades em cada exercício, e, assim, acompanhar detalhadamente a oportunidade e a propriedade das providências levadas a efeito pelo Govêrno. A grande controvérsia que sôbre o princípio da anualidade ainda se sustenta, é a de que pode prejudicar a exiquiibilidade dos planejamentos pluri-anuais, hoje necessários às grandes comunidades nacionais. No nosso ponto-de-vista, a anualidade do orçamento chega mesmo a facilitar êsses planejamentos, já que o Govêrno poderá aquilatar anualmente as suas conseqüências concretas em todos os setores da economia. Além do mais, sendo que o ciclo habitual das transações privadas é de um ano, há realmente utilidade em que algumas atividades financeiras do Govêrno se ajustem à essa circunstância.

O princípio da exatidão corresponde mais aos processos de se estimar a receita e despesa públicas. Esses processos devem ser coerentes e apresentar cifras que se aproximem da realidade o mais possível. A exatidão dos dados orçamentários é uma noção básica que deve exercer importância relevante na fase da elaboração orçamentária, pois dela dependerá o andamento sem estorvos dos negócios administrativos no exercício posterior Se não houver exatidão de dados, a administração pública verse-á na contingência de fazer apêlo constante aos chamados créditos adicionais sem mencionar as possivveis modificações dos pla- 
nos de trabalho de cada repartição em particular, e mesmo da politica governamental, de um modo geral.

A clareza com que deve se apresentar formalmente o orçamento, refere-se ao fato de que ao Govêrno cumpre formular seu plano de ação de maneira compreensivel para a sociedade, e especialmente para a própria Administração Pública. Quando dúvidas surgem quanto à aplicação dos fundos públicos, em virtude de imprevisões e deficiências da demonstração orçamentária, a inquietação transparece no nivel dos negócios privados, no seio da Administração Pública, e até mesmo entre o Povo, que teme que o Estado esteja "coando mosquito, e engulindo camelo" (Mateus: 23:24).

A publicidade do orçamento é um princípio que se liga aos regimes democráticos. O Govêrno precisa colocar a destinaçào dos fundos publicos no conhecimento de todo o pove, a fim de que êsse verilique a qualiáade da administração a que está submetido. "A afirmação de Cavour de que os fundos do Estado devem ser guardados eni caixas de vidro significa que todos r:s cidadãos têm o direito de caber qual a aplicação dada ans recursos exigidos ao povo através da rributação". (42) Aqui no Brasil, apesar de grande parte das sociedades anônimas serem obrigadiss, por lei, a publicar seus balanços em periódicos comuns, o Govêrno publica o Orçamento da União ùnicamente no Diário Oficial, quando deveria fazê-lo em quase todos os principais periódicos do país, em sintese, é claro. A publicação do Orçamento no Diário Oficial, tão sòmente, ou sua apreciação técnica em publicações especializadas, subtrai o conhecimento da ação financeira do Govêrno à maioria dos cidadãos, e deveria ser substituido por uma divulgação mais ampla da lei de meios, inclusive para caracterizar ainda mais o sentido democrático de nossa coletividade.

O principio da exclusividade pretende que sendo o Orçamento um instrumento da administração financeira do Govêrno, não convém que no mesmo constem assuntos não financeiros, ou contenha dispostivos que não possam se traduzir em cifras que estimem a receita ou fixem a despesa para um próximo exercicio. Esse princípio da exclusividade é aceito pacificamente, pelo menos na atualidade, sendo que na fase da elaboração orçamentária, deverá o órgão próprio dispor de técnicas para depurar das propostas parciais de cada nível administrativo assuntos não atinentes especificamente ao orçamento.

Enfim, a problemática dos princípios orçamentários, caminha no sentido de que não devem possuir excessiva rigidez, pois "se a receita prevista deixa de concretizar $-s e$ e se se fazem novos

(42) Sebastião ce Sant'Anna e Silva, op. cit., pág. 53. 
apelos aos recursos do govêrno, o mecanismo orçamentário deve ser capaz de adaptar-se aos novos acontecimentos. Se não o fizer, fracassará". (43)

\section{RECEITA E DESPESA: ASPECTOS RELACIONADOS À TÉCNICA DE ELABOBAÇ.̃̃o}

Todo incurso de moeda no Tesouro Nacional, advindo de prescrição legal, constitui receita pública da União. Por outro lado, tais recursos monetários devem ser auferidos através da organização administrativa do Estado, ou outra entidade de direito público, ficando em disponibilidade no ativo da União. A fim de que tais recursos fiquem em disponibilidade no ativo do Goverrno, e, portanto, sem contra-partida no passivo, cumpre que o Estado através da tributação requisite numerário da renda liquida nacional, ou então obtenha rendimentos também liquidos de suas propriedades ou emprêsas. Nesse sentido, de uma maneira mais geral, como acentuava Adam Smith em 1776, as duas grandes fontes de receita do Estado são: a) aquelas provenientes das propriedade do Govêrno; $b$ ) as derivadas da fortuna do povo (in Sebastião de Sant'Anna e Silva, op. cit., pág. 33). Na atualidade, no sistema de absorção de recursos para o Govêrno, res. saltam-se as seguintes fontes de receita: a) domínio público; b) tributação; c) crédito público; d) operações monetárias e de tesouraria; e) transferências de economia externas; $f$ ) doações internas públicas ou privadas; $g$ ) rendas provenientes do exercício deatribuições governamentais.

No Orçamento da União há uma classificação geral da Receita em Ordinária e Extraordinária, que reflete uma preclara noção de classificação de contas públicas. A complexidade de classificação da receita pública, advém, sobretudo, da diversificação de origens dos recursos que tem penetração no Tesouro Nacional, conforme ficou discriminado acima. No que se refere à Receita Ordin;ria, parece óbvio que as rendas tributárias, as patrimoniais, as industriais, e as diversas (cobrança da divida ativa e multas), devem lhe pertencer pelo simples bom senso das coisas. Entretanto, na Receita Extraordinária cumpriria que constassem as fontes acima especificadas em letras $c, d$, e, e f? Parece que não. Na classificação atual, Receitas Extraordinárias são as seguintes: alienação de bens patrimoniais, adicional sôbre o impôsto de renda para reaparelhamento econômico e impôsto adicional sôbre os lucros das pessoas jurídicas. Essa disposição das receitas extraordinárias no Orçamento da Unnião, baseia-se nos critérios de não habitualidade e de temporariedade. Em 1943, a

(43) Sundelson, in Jurandir Coelho, op. cit., pág. 85. 
situação era bem diferente, já que na chamada "Renda Extraordinária", estavam consignadas contribuições que, "excluidas as de caráter nitidamente tributário (impostos e taxas fàcilmente reconheciveis), podem ser de caráter transitório ou eventual, jamais extraordinário". (44) Naturalmente, a própria evolução dos estudos orçamentários no Brasil, impulsionou a que o Govërno viesse a adotar a forma atual, que, em certos aspectos, corresponde à realidade financeira da União. Está claro que as chamadas operações de crédito, as de tesouraria, os ágios, os "swaps", as transferências externas, alguns tipos de subvenções, sem mencionar as emissões inflacionárias, etc., não participam do Orçamento, nem poderia ser de outra forma, entretanto, deveriam constar de um quadro expositivo do Orçamento, anexo, a fim de que o Govêrno e o povo pudessem saber o que irá acontecer com os fundos públicos, no que concerne a essas transações eminentemente monetárias. "Não serão incluídas ... no orçamento geral ... todavia, as chamadas receitas de compensação, resultantes, por exemplo das operações de crédito e amortização de divida. Seria preferivel, igualmente, dar a certos tipos de operações monetárias, como por exemplo, os lucros resultantes de uma desvalorização da moeda ou as perdas resultantes de uma revalorização, o mesmo tratamento dado às operações de crédito ou à amortização de dívida. Da mesma maneira, deverão ser excluídos os auxílios procedentes do estrangeiro. As operações excluidas das receitas e despesas orçamentárias têm de ser. contudo, incluidas num demonstrativo que apresente a situação consolidada no saldo em dinheiro da administração pública, indicando o método seguido para o financiamento da diferença entre as receitas e despesas totais". (45)

Despesa pública, para os fins dêste trabalho, pode ser entendida como tôda saída de moeda do Tesouro Nacional, através de prescrição legal. Nos critérios utilizados para a classificação da despesa pública, destacam-se os seguintes: a) por funções específicas, ou seja, apresentando as "funções" do Estado de promover o ensino, a agricultura, a construção de rodovias, manutenção e funcionamento das fôrças armadas, etc.; $b$ ) por serviços ou unidades administrativas, especificando o destino de cada dotação para os ministérios, departamentos, repartições, etc.; c) por objeto, especificando se se trata de pessoal, material, etc.; d) por natureza ou caráter, diferenciando as despesas de custeio, investimento, ordinárias, extraordinárias, produtivas, improduti-

(44) Arízio de VianNa, Orşamento Brasileito, pág. 74, 1943, Rio de Janeirol

(45) Nações Unidas, Estrututa do Orçamento e Classificação das Contas Públicas, pág. 14, 1959, Rio de Janeiro. 
vas, etc.; e) por fundos especiais, referindo-se à vinculação de receitas a determinadas despesas governamentais.

O problema de uma classificação mais ou menos perfeita da receita e a despesa públicas, não só nos conduziria, caso fôsse equacionado, ao escôpo sumamente almejável da chamada "verdade orçamentária", como também possibilitaria uma apreciação mais refinada dos problemas ligados ao equilibrio orçamentário. A noção do equilíbrio orçamentário tem variado nos últimos tempos, mòrmente quando em virtude da grande depressão de 1929 , passou-se a se considerar o equilibrio econômico como prevalecente ao equilibrio orçamentário. Quando nos referimos à necessidade de um aperfeiçoamento da sistemática orçamentária no Brasil, no que tange principalmente à unificação dos negócios financeiros públicos, ou seja na adequada restauração do princípio da unidade orçamentária (unidade não formal, mas de fato), tínhamos em perspectiva a obtenção de uma "verdade orçamentária" no quadro financeiro federal, a fim de que se pudesse conhecer a efetiva significação dos deficits já crônicos em nossos orçamentos, pois as nossas leis de meios apresentam apenas um panorama limitado do problema, porque nelas não constam certo número de operações financeiras do Govêrno. Naturalmente, que sòmente com a possibilidade de sistematização de tôdas as operações do Govêrno num só jôgo orçamentário, dará ensêjo a que se faça uma apreciação técnica do equilibrio orçamentário. "A função financeira de manter o equilibrio exige um tratamento unificado de tôdas as despesas e receitas; requer que nenhuma parcela do material incluido no sistema orçamentário seja considerada separadamente ou à parte das finanças ordinárias e que não lhe seja concedida personalidade própria. Poucos argumentos são necessários para justificar o princípio da unidade em qualquer orçamento". (46) Esse mesmo SundeLson da citação anterior, diz que "a separação de itens financeiros num sistema de orçamentos múltiplos não tem grande significação em si mesma, mas uma política aos desvios da unidade orçamentária". (47) Assim, estando o Govêrno de posse dos elementos de tôda a sua ação financeira, irá dispor do aparato necessário para averiguar a propriedade de sua política financeira, sobretudo dos problemas atinentes ao equilíbrio orçamentário. Convém, entretanto, que não se considere o equilibrio orçamentário como um fim em si mesmo, antes como conceito que deverá sofrer variações ante as imposições econômico-sociais da época. A noção do equilibrio orçamentário anual, por outro lado, pouca significação tem, em virtude do fato de que os ciclos econômicos não se

(46) Sundelson, in Jurandir Coelho, op. cit., pág. 81.

(47) Sundelson, in Jurandip Coelho, op. cit., pág. 81, rodapé. 
enquadram na obrigatoriedade cósmica de uma rotação total da Terra ao redor do Sol, e é óbvio que cumpre antes ressalvar a economia de depressões, ou amenizar seus efeitos, do que manter um equilibrio orçamentário numa situação de redução progressiva de preços, de desemprêgo, de diminuição da demanda global, etc. "Constituye un error arcaico que el gobierno debe equilibrar cada año su presupuesto, cualesquiera que sean las circunstancias. Por qué no entonces equilibrarlo cada mes, cada semana o cada hora?". (48) A noção de equilíbrio tem variado, sobretudo, ante a consideração das chamadas "contas de capital", de um lado, em contraposição às "contas de exploração" ou "contas de operações correntes", de outro lado. Dessa forma, "l'équilibre budgétaire est réalisé lorsque les ressources courantes suffisent pour faire face aux dépenses d'exploitation. Il n'y a pas déficit mo ment que l'excedent des dépenses sur les recettes normales se traduit par une création de biens matériels rentables ou simplement productifs de services". (49) O sentido técnico das des pesas de capital é o que traduz o "valor liquido das contribui ções para o aumento do ativo real do Estado". (50) Diante dessa noção básica, verifica -se a importâância que as despesas de capital tem para com o chamado orçamento cíclico. Sem embargo de que as contas de operações correntes influenciam gran demente na utilidade econômica dos fundos públicos, nota-se que as despesas de capital, pelo seu aspecto de renovação do equipamento de capital do Estado, e, também, em certo sentido, com repercussões em tôda a economia, exercem uma função muito mais preponderante. A aplicação da despesa pública, através da técnica de orçamentos cíclicos, deverá observar, principalmente o seguinte:

a) como técnica de erradicação do desemprêgo (chomage) através da execução de programas de obras públicas de grande envergadura;

b) num aspecto positivo, através da expansão dos gastos, procurar-se-á a restauração do equilibrio entre a oferta global e a procura global, nas fases de crise ou recessão;

c) num aspecto negativo, através da redução de gastos, poder-se-á deter o processo inflacionário, isto é, usa-se a despesa como técnica deflacionária;

d) procurar-se-á, por outro lado, compreender, para a política governamental, em matéria de gastos, as devidas conseqüências do princípio multiplicador;

(48) Jacob Viner, in Hugh Dalton, op. cit., pág. 339.

(49) Laufenburger, ợ. cit.. pág. 5.

(50) Nações Unidas, ợ ’ cit., pág. 28. 
e) nos paises desenvolvidos ou regióes desenvolvidas, deverão crescer contìnuamente os gastos destinados a investimentos ou gastos de capital, e, nos países sub-desenvolvidos, os gastos especificamente destinados à promoção do desenvolvimento econômico;

f) também, as despesas de transferências, cada vez maiores, deverão ser utilizadas como técnica para promover a redistribuição da renda nacional;

g) subvenções deverão ser canalizadas adequadamente visando à alta de preços, em favor dos produtores, ou à baixa de preços, em favor dos consumidores;

h) promover-se-á a aquisição e estocagem de bens com o fim de manter o desenvolvimento equilibrado do mercado.

Em épocas de depressão, em sintese, caberá ao govêrno ampliar seus gastos e diminuir os encargos fiscais, e, em épocas de prosperidades, diminuir os gastos e aumentar os encargos fiscais, a fim de controlar o aumento exagerado dos negócios. Claro está, que na prática orçamentária tais procedimentos deveriam estar convenientementt ligados a um sistema de planejamento econômico do Govêrno, que objetivasse sobretudo ao atendimento das necessidades progressivas, à hamonização das tensões, e à distribuição adequada de benefícios e recursos nas classes sociais. No Brasil, a maior dificuldade para o serviço público, ao que nos parece, é a ausência de um processo continuado de planejamento, o que constitui falha injustificável, já que em nações modernas o planejamento constitui-se como coisa de rotina. Essa deficiência decorre em grande parte de duas razões: a primeira é a de que a Divisão de Orçamento e Organização do D.A.S.P., incumbida da elaboração da proposta orçamentária, não age em conjunção com os organismos de planejamento da União, ou seja, com a Comissão Nacional de Planejamento e a Comissão Nacional de Desenvolvimento; a segunda, é a de que a proposta orçamentária é elaborada de uma forma, que inevitàvelmente fica desfigurada na sua tramitação no Congresso Nacional, o que está a exigir uma participação efetiva e coordenada do Legislativo na elaboração da proposta orçamentária, em sistema de cooperação com aquêle organismo federal especializado. Aliás, num regime parlamentar, deve-se preferir a ampla participação dos representantes do poxo nas principais funções administrativas do Govêrno, é claro que convenientemente dosada e organizada, a fim de se evitar o alvoroço, ou seja, apenas a irrupção de divergências no decurso dos trabalhos. 


\section{A ESTIMATIVA DA RECEITA E DESPESA PÚBLICAS, E SUA IMPORTÂNCIA PARA A TÉCNICA DE ELABORACÃO}

Apesar do grande desenvolvimento técnico que os procedimentos de estimar a receita e a despesa públicas, tiveram nos últimos tempos, ainda é correta a afirmação de STourm de que para a formulação de "justas avaliações" é sobretudo importante a conjugação de duas qualidades de quem prepara o Orçamento: a sagacidade e a sinceridade. "La sagacité permet aux préparateurs du budget de voir clair dans l'avenir, aussi clair que possible. La sincérité les engage à déclarer da vérité, lorsqui'ils l'ont discernée". (51) Na fase da elaboração orçamentária, o problema da estimativa da receita se apresenta como dos mais transcendentais, já que sua imprecisão poderá conduzir o Govêrno à prodigalidade dos gastos, na hipótese de uma estimativa a maior, ou então ao não atendimento de gastos essenciais à administração, quando essa estimativa fôr pessimista. Os processos utilizados na estimativa das receitas são os seguintes:

a) automático, que reputa o volume da receita do último exercício liquidado, como estimativa para o exercício próximo;

b) das majorações, que acrescenta ao resultado do último exercicio liquidado, a média aritmética dos acréscimos verificados nas arrecadações dos três ou cinco últimos anos;

c) das médias, que consiste em procurar a média aritmética das arrecadações de três, cinco, ou mais anos, considerando-a como provável receita no exercício a seguir;

d) da extrapolação, que é um procedimento estatístico, que identitica a receita do exercício vindouro através da linha curvilinea de tendência das arrecadações dos exercícios já encerrados;

e) da avaliação direta, que considera as informações do passado, confrontando-as com as situações do momento e tam bém com as possibilidades da economia nacional no período futuro. Os quatro primeiros métodos são considerados ineficazes, em virtude de que os fenômenos econômico-sociais são absolutamente indenes de meras considerações matemáticas ou de estatísticas simples. O método de extrapolação, apesar de se basear em elementos estatísticos, tem a sua maior ineficiência, ou insuficiência, justamente porque considera os fatos de forma muito global, sem levar em consideração o conteúdo das diferentes variāveis que integram o conjunto. O sistema de avaliação direta, entretanto, oferece uma base bem aproximada da realidade financeira no exercício próximo, devendo ser aplicado na fase de elaboração orçamentária. O sistema de avaliação direta, que foi

(51) René Stourn, Le Budgef, pág. 156, 1889, Paris. 
cognominado de "método sem método", na verdade é um método altamente especializado e exige requintes técnicos os mais avançados.

Esse sistema deverá comprender estudos sôbre:

a) capacidade tributária da sociedade, e suas possiveis oscilações diante do aperfeiçoamento administrativo da máquina fiscal; diante das variações da produtividade industrial, agrícola, de serviços, e bem assim das condições de comércio exterior e do volume de negócios em geral;

b) indices de crescimento demográfico, sobretudo no que se refere à população ativa, ou seja à mão-de-obra que estará em disponibilidade em determinada ocasião;

c) evolução dos sistemas de transporte e comunicações;

d) recursos naturais que estão em perspectiva de utilização imediata pela estrutura econômica;

e) influências diversificadas de caráter social, político, militar, ético, administrtivo, etc., que podem alterar os componentes da produção econômica.

A simples menção dêsses quesitos identifica a extrema complexidade da estimativa da receita pela avaliação direta. Tais informações só seriam possiveis mediante estatísticas econômicas e financeiras as mais complexas possiveis, e atualissimas.

Já a estimativa de despesa, deverá expressar com clareza as dotações julgadas necessárias à manutenção e ao funcionamento dos serviços públicos, não só no nível das unidades menores da administração pública, como também no nível departamental e ministerial. Naturalmente, que a avaliação da despesa deverá atender para a possibilidade de elevação do nivel de preços do mercado, mòrmente no que diz respeito aos preços dos bens e serviços mais amplamente usados na Administração Pública. Aqui no Brasil, as diferenças entre os dados constantes da proposta orçamentária e sua respectiva execução devem-se, sobretudo, aos seguintes itens:

a) instabilidade monetária, conduzindo à elevação dos preços de bens e serviços de consumo na esfera administrativa federal;

b) acréscimos de dotações no Congresso Nacional, cuja numeerabilidade na apresentação de emendas à lei de meios não apresenta equivalente em lugar nenhum do mundo;

c) a circunstância de se desconhecer, "a priori", "da capacidade de financiamento das despesas públicas pelo Tesouro Nacional"; (52)

(52) Conjuntura Econônica, maio, 1961, pág. 87, Rio de Janeiro. 
d) de curso extremamente amplo, dois anos, da fase de elaboração à de execução;

e) constante alteração das leis que fixam despesas e criam novas formas tributárias, ou novas aliquotas para a tributação em vigor;

f) dispositivos do Código de Contabilidade da União que libera verbas mesmo quando há "insuficiência de dotação para atender ao pagamento ordinário do pessoal, pois nessa eventualidade nenhum prejuízo sofre a repartição atingida, dado o artifício permitido pelo dispositivo do Código de Contabilidade que dispõe sôbre a matéria"; (53)

g) elevado volume de créditos adicionais;

h) gastos extra-orçamentários;

i) vinculação de despesas.

Algumas das questões acima estipuladas ficam à margem da técnica de elaboração orçamentária pròpriamente dita, tal como a instabilidade monetária, que também "en. France, l'expérience a démontré qu'en période d'instamilité monétaire, notament, la prévision initiale des dépenses apelle au bout de quelques mois des corrections substantielles", (54) pertencem mais à situação da conjuntura econômica, e não dependem nem da "sagacidade" e nem da "sinceridade" dos organizadores da proposta orçamentária. Por outro lado, outras questões demandam modificações $\mathrm{em}$ nossa estrutura jurídica, cujo caráter sumamente antiquado, em quase todos os setores, constitui indisfarçável e incômoda verberação à "sagacidade" e à "sinceridade"... dos indivíduos incumbidos de legislar no Brasil, o que aliás não se pode imputar só aos parlamentares atuais, pois é problema que se estende pràticamente ao longo de nossa história republicana.

O impulso econômico que foi dado ao Brasil, principalmente a partir dos anos quarenta, consolidou de tal forma o sistema de desenvolvimento de sua estrutura de produção, que é quase impossivel qualquer movimento regressivo. Todavia, um dos maiores impecilhos à plena liberação de nossas potencialidades econômicas e sociais, é a inadequação da organização do Estado brasileiro à dinâmica e às solicitações das condições atuais, consequêencia de uma estrutura juridica obsoleta. Quando o promover dessa adequação do Estado à sociedade não depende mais do discernimento dos titulares do poder, e sim de sua vontade, e,

(53) Conjuntura Econômica, idem, pág. 88.

(54) Lauifenburger, op. cit., pág. 13. 
apesar disso não se concretiza, torna-se inevitável o desprestígio do Govêrno, o que poderá acarretar dificuldades à manutenção do regime democrático.

\section{CONCLUSÕES}

19) que, cumpre estabelecer um sistema de $O$ \& $M$ na Administração Pública brasileira, cujo centro fique coordenado à Divisão de Orçamento e Organização do D.A.S.P.

2.) que, cumpre estabelecer um sistema continuado de planejamento na Administração Pública brasileira, cujo centro fique coordenado à Divisão de Orçamento e Organização do D.A.S.P.

39) que, cumpre submeter as autarquias, sociedades de economia mista, e outras entidades semi-públicas que exercem funçôes de interêsse público, relacionadas com o Tesouro Nacional, ao mesmo sistema orçamentário vigente para a União.

49) que, cumpre fazer um demonstrativo das contas públicas que não se enquadrem no sistema orçamentário vigente no Brasil.

5\%) que, cumpre fazer ampla divulgação do Orçamento da União em todo o território nacional. 